\title{
Flies (Calliphoridae, Muscidae) and Beetles (Silphidae) from Human Cadavers in Cali, Colombia
}

\author{
Mauricio Barreto+ ${ }^{+}$María Elena Burbano, Pablo Barreto
}

\author{
Departamento de Microbiología, Facultad de Salud, Universidad del Valle, A.A. 25360 Cali, Valle, Colombia
}

Adult specimens of Cochliomyia macellaria, Chrysomya megacephala, Ch. rufifacies, Lucilia sp. (Calliphoridae), Musca domestica (Muscidae), Oxelytrum discicolle (Silphidae) and Sarcophagidae were recovered from 12 human cadavers in Cali, Valle, Colombia. Information regarding these findings is presented.

Key words: Chrysomya rufifacies - Chrysomya megacephala - Oxelytrum - forensic entomology - Colombia

Identifications of insects associated with human cadavers are relatively few in the literature of the Neotropical region. Dunn (1916) reported Hermetia illuscens (L.), a stratiomyid in Panama; Pessôa and Lane (1941) presented previous records and reviewed necrophilous Scarabaeidae from museums in Brazil; Jirón (1979), Jirón et al. (1983), Jirón and Solano (1988) gave information on Calliphoridae, Sarcophagidae, Muscidae and Stratiomyidae of Costa Rica; and Carvalho et al. (2000) identified arthropods associated with pig carrion and human corpses in Campinas, State of São Paulo, Brazil. Recently, some experimental studies of forensic entomology have been carried out in different regions of Colombia (Idrobo \& Martínez 2000, Restrepo et al. 2000, Wolff \& Uribe 2000). In Cali ( $3^{\circ} 26^{\prime} \mathrm{N}, 76^{\circ} 31^{\prime} \mathrm{W}$, $1,000 \mathrm{~m})$, Olaya (1999) determined the arthropod succession and the rates of decomposition in dogs, but apparently no specific identifications of insects found on human bodies have been published.

During different months of 1990 and 1991 insects found on 16 human cadavers (14 men, 2 women) were collected at the Cali Institute of Legal Medicine. The human bodies were in early stages of decomposition (fresh or bloat) and they were found in urban and rural areas of the city, on empty grass or bush fields. The victims, fully-clothed or half naked, had bullets and/or stab wounds, and some were strangled. The insects captured were preserved in alcohol and some were pinned, later in the entomology laboratory. The identifications of the Calliphoridae were made with the work of Dear (1985); diagnoses of these and some other flies were confirmed by Dr B Greenberg (University of Illinois at Chicago). Specimens were deposited in the Arthropod Reference Collection of the Departamento de Microbiología, Facultad de Salud, Universidad del Valle.

A total of 70 adult insects were collected from 12 human bodies; the other 4 corpses contained only larvae and/or eggs of flies. The species and number of adult insects recovered are given in the Table. Also, 2 female Sarcophagidae were obtained from one cadaver, fly larvae and eggs were present on 11 and 5 cadavers, respectively.

\footnotetext{
${ }^{+}$Corresponding author. Fax: +90572-5542468. E-mail: mbarreto@mafalda.univalle.edu.co

Received 8 March 2001

Accepted 21 August 2001
}

The Calliphoridae included Chrysomya megacephala (F.) and Ch. rufifacies (Macquart), species that arrived in South and Central America from Africa and the Australasian region, respectively (Baumgartner \& Greenberg 1984). Both species have been recorded in North America (Greenberg 1988) and were also found on dogs carcasses in the study of Olaya (1999).

The dispersion of the Chrysomya species from Brazil and Costa Rica to the north has been more studied than the movement of Ch. rufifacies to the south (Baumgartner 1993). Besides the record of two specimens of this species by Mariluis and Schnack (1989) in Buenos Aires, Argentina, no further information has been obtained in South America. The present records from Cali are apparently the first for Colombia. This species was the most abundant on the human cadavers examined, but the proportion of the native Cochliomyia macellaria (F.) was also high, indicating a less severe competition than in other areas (Baumgartner \& Greenberg 1985) or experimental works (Wells \& Greenberg 1992a,b). More field controlled studies are necessary to confirm these preliminary observations and to establish basic forensic entomology information at Cali.

\section{ACKNOWLEDGMENTS}

To Dr JL Arredondo for collecting some of the specimens, and to Dr B Greenberg for identification of material and suggestions to the manuscript.

\section{REFERENCES}

Baumgartner DL 1993. Review of Chrysomya rufifacies (Diptera: Calliphoridae). J Med Entomol 30: 338-352.

Baumgartner DL, Greenberg B 1984. The genus Chrysomya (Diptera: Calliphoridae) in the New World. J Med Entomol 21: 105-113.

Baumgartner DL, Greenberg B 1985. Distribution and medical ecology of blow flies (Diptera: Calliphoridae) of Peru. Ann Entomol Soc Am 78: 565-587.

Carvalho LML, Thyssen PJ, Linhares AX, Palhares FAB 2000. A checklist of arthropods associated with pig carrion and human corpses in southeastern Brazil. Mem Inst Oswaldo Cruz 95: 135-138.

Dear JP 1985. A revision of the New World Chrysomyini (Diptera: Calliphoridae). Rev Bras Zool 3: 109-169.

Dunn LH 1916. Hermetia illuscens breeding in a human cadaver (Dipt.) Entomol News 27: 59-61.

Greenberg B 1988. Chrysomya megacephala (F.) (Diptera: Calliphoridae) collected in North America and notes on Chrysomya species present in the New World. J Med Entomol 25: 199-200. 
TABLE

Adult Calliphoridae, Muscidae and Silphidae found on fresh or bloat murdered human bodies (\% of 12 cadavers)

\begin{tabular}{lllrrr}
\hline Order & Genus & Species & Females & Males & Cadavers \\
\hline Diptera & Cochliomyia & macellaria & 11 & 0 & 7 \\
& Chysomya & megacephala & 9 & 0 & 6 \\
& Chrysomya & rufifacies & 41 & 1 & 1 \\
& Lucilia & sp. & 1 & 0 & 1 \\
Coleoptera & Musca & domestica & 2 & 0 & 1 \\
& Oxelytrum & discicolle & 3 & 0 & 8 \\
\hline
\end{tabular}

Idrobo CJ, Martínez WA 2000. Interrelaciones de insectos asociados a hígado humano en descomposición, Popayán, Colombia. Resúmenes Congr Soc Col Entomol 27, p. 98.

Jirón LF 1979. Sobre moscas califóridas de Costa Rica (Diptera: Cyclorrhapha). Brenesia 16: 221-222.

Jirón LF, Solano ME 1988. Notes on the eclectical feeding preferences of the black soldier fly Hermetia illuscens (Diptera: Stratiomyidae) in Costa Rica. Brenesia 30: 101-103.

Jirón LF, Vargas LG, Vargas-Alvarado E 1982. Four muscoid flies (Sarcophagidae and Muscidae) associated with human cadavers in Costa Rica. Brenesia 21: 1-5.

Mariluis JC, Schnack JA 1989. Ecology of the blow flies of an eusynanthropic habitat near Buenos Aires (Diptera, Calliphoridae). Eos 65: 93-101.

Olaya LA 1999. Estudio de la Entomofauna Sucesional en el Cadáver de dos Cánidos en Condiciones de Campo, BSc Thesis, Universidad del Valle, Cali, Colombia, 96 pp.

Pessôa SB, Lane F 1941. Coleópteros necrófagos de interésse médico-legal. Ensáio monográfico sôbre a familia Scarabaeidae de São Paulo e regiões vizinhas. Arq Zool Est São Paulo, II. Rev Mus Paulista 25: 389-504.

Restrepo F, Valderrama R, Marín MA, Cadavid GA 2000. Artropofauna cadavérica asociada con los estados de descomposición del intervalo post-mortem en el cerdo Sus scrofa, en dos medios ecológicos diferentes. Resúmenes Congr Soc Col Entomol 27, p. 93.

Wells JD, Greenberg B 1992a. Interaction between Chrysomya rufifacies and Cochliomyia macellaria (Diptera: Calliphoridae): the possible consequences of an invasion. Bull Entomol Res 82: $133-137$

Wells JD, Greenberg B 1992b. Laboratory interaction between introduced Chrysomya rufifacies and native Cochliomyia macellaria (Diptera: Calliphoridae). Environ Entomol 21: 640-645.

Wolff M, Uribe A 2000. Sucesión de insectos carroñeros en cerdo blanco (Sus scrofa). Memorias Congr Soc Col Entomol 27: 177-185. 